\title{
The Molecular Mechanism of Protoplasmic Incompatibility and its Relationship to the Formation of Protoperithecia in Podospora anserina
}

\author{
By H. BOUCHERIE, J. BEGUERET AND J. BERNET \\ Laboratoire de Génétique, University of Bordeaux, 33405, Talence, France
}

(Received 3 March 1975; revised 29 May 1975)

SUMMARY

In Podospora anserina, protoplasmic incompatibility due to interactions between non-allelic genes was suppressed by the effect of mutations in two modifier genes, mod-I and mod-2. It is shown that mod-I and mod-2 are involved in the production of three specific proteins, a phenoloxidase and two previously identified proteases (Bégueret \& Bernet, 1973a) which are associated with the phenomenon of protoplasmic disintegration. These enzymes, whose messengers are normally latent during vegetative growth, appear at this stage of the life cycle only as a consequence of incompatible gene interactions.

The mod-I and mod-2 genes and each of the five incompatibility loci involved in non-allelic incompatibility systems also participate in the formation of the protoperithecia. This pleiotropic effect suggests that protoplasmic incompatibility is a deviation in the normal physiological processes of protoperithecial formation.

\section{INTRODUCTION}

Studies on protoplasmic incompatibility, a phenomenon of cytoplasmic lysis induced by the fusion of cells of unlike genotypes, have been reported in many fungi, including Neurospora crassa (Garnjobst \& Wilson, 1956), Didymium iridis (Collins \& Clark, 1968), Physarum polycepharum (Carlile \& Dee, 1967) and Podospora anserina. The first extensive genetic studies (Rizet \& Esser, 1952; Bernet, 1967) and biochemical investigations (Blaich \& Esser, 1971 ; Bégueret, 1972) of this phenomenon were on $P$. anserina.

In $P$. anserina, incompatibility genes occur at nine loci. The five loci, $c, d, e, r$ and $v$, are involved in the three non-allelic incompatibility systems $C / D, C / E, R / V$, and the $v$ locus is also concerned in the allelic $V / v I$ system. Most of the genetic investigations have been performed on the non-allelic systems, and allelic series were found at the $c, d$, and $e$ loci giving rise to several $C / D$ and $C / E$ systems (Bernet, 1967). Physiological suppression of the protoplasmic incompatibility reaction between two strains that carry antagonistic genes, i.e. between strains $C$ and $D, C$ and $E$ or $R$ and $V$, requires the presence in both strains of a mutation in each of the modifier genes mod-I and mod-2 (Bernet, 197I).

Biochemical investigations have been performed on the $R / V$ system because of its temperature dependence. At $32^{\circ} \mathrm{C}$, the $R V$ strain, which combines the non-allelic incompatible $R$ and $V$ alleles, exhibits the wild-type phenotype, but at $26^{\circ} \mathrm{C}$ growth stops early in development and the cells lyse, as in the homologous $C D$ or $C E$ strains. When self-lysis was induced in $R V$ cells by a temperature shift from 32 to $26^{\circ} \mathrm{C}$, proteases III and IV (enzymes which are absent from normal cells) were found (Bégueret \& Bernet, 1973a). Furthermore, the addition of protease inhibitors such as phenyl methyl sulphonyl fluoride or $\beta$-phenyl pyruvic acid either reduced or completely abolished cell disintegration (Bégueret, 1973). The lytic 
reaction was also prevented by cycloheximide but not by actinomycin $\mathrm{D}$ or 5 -fiuorouracil (Bégueret \& Bernet, 1973b). Thus, it was postulated that protoplasmic incompatibility in $P$. anserina is due to proteolytic enzymes formed from messengers existing in the cells before the interaction between incompatibility factors (Bégueret, 1973; Bégueret \& Bernet, 1973 $a, b$ ).

Additional evidence for the involvement of proteases III and IV in cell disintegration is provided by investigations of strains carrying mutations at the mod-I and mod-2 genes which suppress protoplasmic incompatibility. We here show that the production of proteases III and IV and of a novel enzyme, a phenoloxidase which like the proteases appears only in lysing cells, is affected by mutations in the mod-I and mod-2 genes.

The mod mutations have an additional effect. In strains carrying mutations at mod-I and mod-2 loci, protoperithecial formation is blocked prior to early steps in their morphological differentiation (Boucherie, 1973). This pleiotropic effect of the mod mutations suggests a connexion between the incompatibility process and the formation of the female organs, and has led us to investigate whether the incompatibility genes might themselves be involved, like the mod genes, in protoperithecial development. Preliminary results (Boucherie \& Bernet, 1974) revealed such a role for the incompatibility genes at the $d$ and $e$ loci. We show here that each of the five incompatibility loci involved in the non-allelic interactions also plays a role in protoperithecium formation.

\section{METHODS}

Origin of $R V$ strains. The cross $+V r \times v_{1} R$ was the source of the conditional lethal selflysing $R V$ strains. For $R V$ strains carrying mutations in the modifier genes mod- $I$ and/or mod-2, these mutations were introduced from the male parent $v_{1} R$. The particular mod mutations used, $\bmod -I(I)$ and $\bmod -2(I)$, are the most efficient for the suppression of protoplasmic incompatibility and protoperithecium formation. In standard conditions $\left(26^{\circ} \mathrm{C}\right)$, double mutant mod-I(I) mod-2(I) strains are nearly female sterile.

Origin of the recombinant $c d$ e $r v$ strains. These strains were derived from crosses between the three geographical races (A), (F) and (s). Progeny from the initial cross + (A) $\times \hat{\sigma}(\mathrm{F})$ were crossed with the (s) race and the appropriate $c d$ er $v$ combinations selected. Mutations $\bmod -I(I), \bmod -2(I)$, or $\bmod -I(I)+\bmod -2(I)$ were added to these genotypes by a further cross with an (s) strain that carried both mutations. For each of the various $c d e r v$ genotypes, four strains of each mating type were examined for the production of protoperithecia.

Preparation of cell-free extracts. Mycelia were grown in $100 \mathrm{ml}$ liquid synthetic medium (Esser, 1969) in $1000 \mathrm{ml}$ Roux bottles incubated at the desired temperature for 4 days. The mycelium was filtered through cheese cloth on a Buchner funnel, rinsed twice with cold distilled water and ground in a glass bead homogenizer in phosphate buffer $(0.05 \mathrm{M}, \mathrm{pH} 7 \cdot 0$, plus $10^{-3} \mathrm{M}$-dithiothreitol). About $\mathrm{I} 60 \mathrm{~g}$ wet wt mycelium was used in each experiment. The homogenate was centrifuged for $30 \mathrm{~min}$ at $20000 \mathrm{~g}$ to remove glass beads and cell debris. Solid $\left(\mathrm{NH}_{4}\right)_{2} \mathrm{SO}_{4}$ was added to the crude extracts up to $90 \%$ saturation at $4{ }^{\circ} \mathrm{C}$. The precipitate was collected by centrifugation and dissolved in a minimum volume of phosphate buffer (0.01 $\mathrm{M}, \mathrm{pH} 7$, plus $\mathrm{IO}^{-4} \mathrm{M}$-dithiothreitol). After dialysis the insoluble material was discarded and the extract mixed with 2 vol. cold acetone and kept for $7 \mathrm{~h}$ at $-15{ }^{\circ} \mathrm{C}$. The precipitate was recovered and suspended in a minimum volume of tris- $\mathrm{HCl}$ buffer $(0.0 \mathrm{O} \mathrm{M}$, $\mathrm{pH} 8$, plus $10^{-4} \mathrm{M}$-dithiothreitol) and exhaustively dialysed against this buffer. After dialysis the insoluble material was removed by centrifugation.

Chromatographic procedures. The soluble fraction was loaded on a TEAE-cellulose column $(400 \times 25 \mathrm{~mm})$ previously equilibrated with the tris buffer. The column was washed 
overnight and the proteins were eluted by increasing $\mathrm{NaCl}$ concentrations $(0 \rightarrow 0.5 \mathrm{M}$ linear gradient). The flow rate was adjusted to $10 \mathrm{ml} / \mathrm{h}$ and $6 \mathrm{ml}$ fractions were collected.

Proteolytic activity measurements. Extract $(0.25 \mathrm{ml})$ was incubated for $30 \mathrm{~min}$ at $37^{\circ} \mathrm{C}$ with $0.25 \mathrm{ml}$ of a $\mathrm{I} \%(\mathrm{w} / \mathrm{v})$ casein solution (phosphate buffer $0.0 \mathrm{I} \mathrm{M}, \mathrm{pH} 6.7$ ). The reaction was stopped by adding I ml of $20 \%$ (w/v) trichloroacetic acid. The $E_{280}$ of the supernatant was measured against a blank in which the reaction was stopped at zero time. One unit of proteolytic activity refers to the amount of enzyme that produces an extinction change equivalent to $\mathrm{IO}^{-4} \mathrm{M}$-tyrosine.

Phenoloxidase measurements. Phenoloxidases were analysed in crude extracts by polyacrilamide gel electrophoresis. Crude extracts $(10 \mu \mathrm{l})$ were applied at the top of $7.5 \%(\mathrm{w} / \mathrm{v})$ polyacrilamide gels (0.15 M-tris-glycine buffer, $\mathrm{pH} 8.5$ ). Constant current (2.5 mA/gel) was applied until the bromophenol blue used as marker reached the bottom of the tubes. Gels were then incubated for $20 \mathrm{~min}$ at $30^{\circ} \mathrm{C}$ in a $0.02 \mathrm{M} \mathrm{DL-3,4}$-dihydroxyphenylalanine solution (in $0.05 \mathrm{M}$-phosphate buffer $\mathrm{pH} 6$ ). The activity of the phenoloxidases is revealed by the appearance of a reddish pigment, the intensity of which was measured by spectrophotometric scanning.

Female fertility determinations. Protoperithecia do not occur before the mycelia have reached the edge of the Petri dish $(9 \mathrm{~cm}$ diam). To investigate female fertility, strains were grown on Rizet's medium and were exposed to light for five days after the cessation of growth (Rizet \& Engelman, 1949).

\section{RESULTS}

\section{Effect of mutations in mod-I and mod-2 genes on the proteolytic enzymes}

Three proteases were found in cell extracts of normal strains (Bégueret \& Bernet, 1973a). The first eluted, proteases $\mathbf{A}$ and $\mathbf{B}$, were both sensitive to ovomucoid, $p$-chloromercuribenzoate and phenyl methyl sulphonyl fluoride but differed from each other in molecular weight and $\mathrm{pH}$-dependence. The third, protease $\mathrm{C}$, was an acid endopeptidase insensitive to these inhibitors. These three proteases were similarly found in the extracts from the $R V$ strains cultured at $32^{\circ} \mathrm{C}$ (Fig. I $a$ ) whether these carried the mod-I $(I)$ and mod-2(I) mutations or not, indicating that these genes are not involved in the formation of proteases A, B or C.

Release of the incompatibility reaction in the $R V$ strain by lowering the temperature from 32 to $26^{\circ} \mathrm{C}$, was followed after $2 \mathrm{~h}$ by an increase in the protease level. When the extraction was performed after the strain had spent $12 \mathrm{~h}$ at $26^{\circ} \mathrm{C}$, proteolytic activity was distributed between four different fractions (Bégueret \& Bernet, 1973a). These corresponded to proteases $\mathrm{A}$ and $\mathrm{B}$, which eluted first and represented $10 \%$ of the total proteolytic activity, and two novel acid endopeptidases, proteases III and IV, that were different from protease C. The latter was never found in lysing cells.

When the $R V$ strain carried the mod-2(I) mutation, the elution profile of the proteolytic activity found in the lysing cells was unchanged (Fig. I $b$ ). It can thus be concluded that the $\bmod -2(I)$ mutation alone has no effect on any of the proteolytic enzymes. For $R \cdot V \bmod -I(I)$,

strain in which the temperature shift also induces the protoplasmic self-lysis reaction, protease III was not detected (Fig. I c), indicating that the mod-I gene is involved in the formation of protease III and that protease IV is sufficient for cell disintegration. In the double mutant $R V$ mod-I(I) mod-2(I) strain where the temperature shift did not lead to cell lysis, protease III was still absent and the level of protease IV was reduced to about $5 \%$ of that found with the $R V \bmod -\boldsymbol{I}(\boldsymbol{I})$ strain (Fig. I $d$ ). Of the five proteolytic enzymes detected in the fungus, proteases A, B, C, III and IV, only III and IV, which are specific to lysing cells, are affected by mutations in the mod-I and mod-2 genes. 

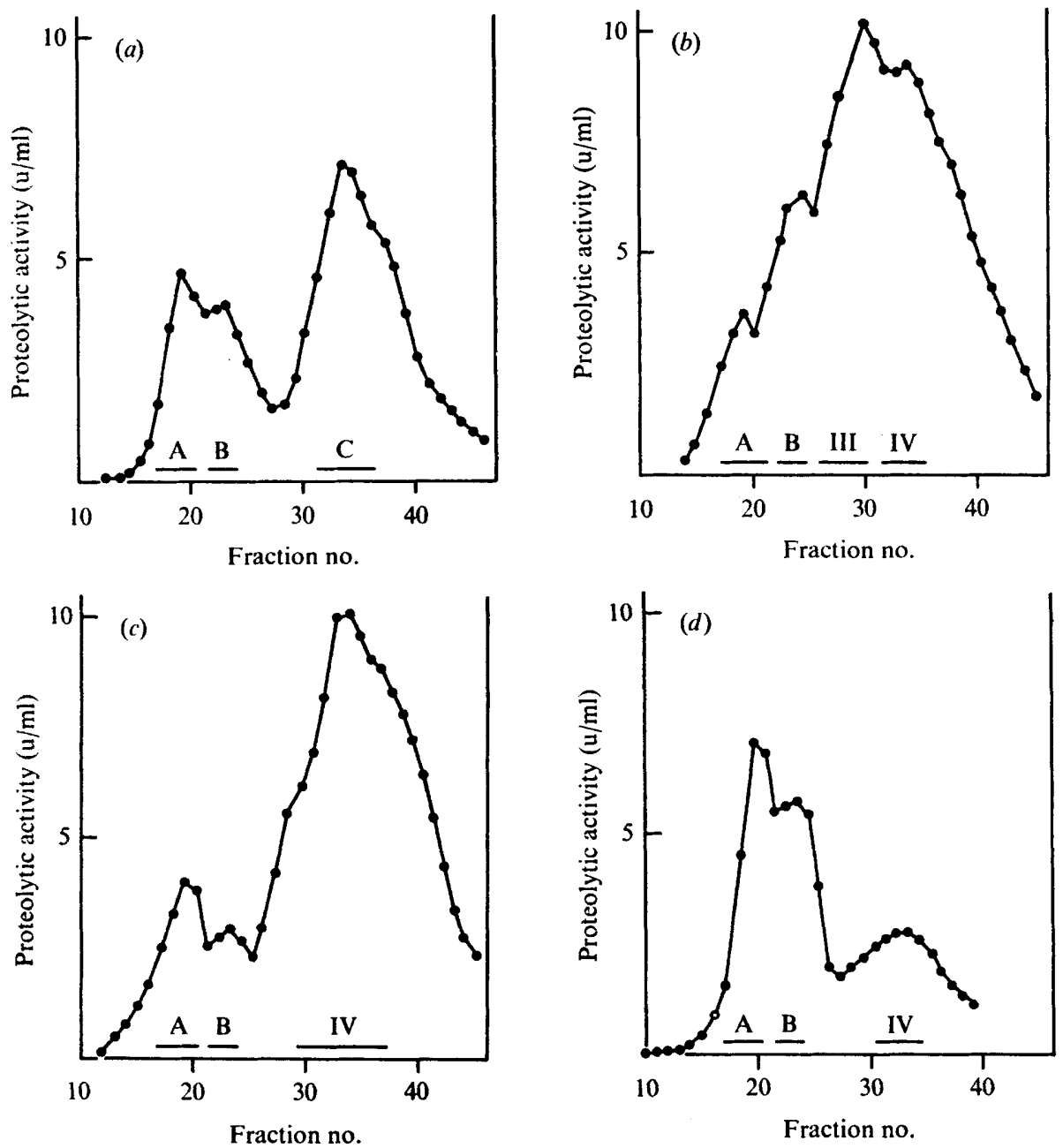

Fig. 1. Elution profiles on a TEAE-cellulose column of the proteolytic activity from a $R V$ strain cultured at $32{ }^{\circ} \mathrm{C}(a)$, and from strains $R V \bmod -2(I)(b), R V \bmod -I(I)(c)$ and $R V \bmod -I(I) \bmod -2(I)$ $(d)$ cultured 4 days at $32{ }^{\circ} \mathrm{C}$ and shifted to $26^{\circ} \mathrm{C}$ for $12 \mathrm{~h}$. Underlined fractions were pooled and further analysed by chromatography on DEAE-Sephadex and then on G-100 Sephadex. Each enzyme was tested for pH dependence and sensitivity towards the inhibitors ovomucoid, phenyl methyl sulphonyl fluoride and p-chloromercuribenzoate to allow comparisons with proteases A, B, C, III and IV (Bégueret \& Bernet, 1973a).

\section{Effect of the mod mutations on the phenoloxidases}

In crude extracts from a normal strain, or from a $R V$ strain cultured at $32^{\circ} \mathrm{C}$, a single phenoloxidase was present, phenoloxidase $A$. This was temperature-sensitive and exhibited a $R_{\mathrm{F}}$ of $0 \cdot \mathrm{I}$. When the $R V$ strain was shifted to $26^{\circ} \mathrm{C}$ an additional enzyme was found, phenoloxidase B. This was temperature-resistant and exhibited a $R_{\mathrm{F}}$ of $0 \cdot 3$. These features resemble those previously described for laccases I and III (Esser, 1963).

To determine whether phenoloxidase $\mathrm{B}$ is synthesized in $R V$ strains as a consequence of the temperature shift, actinomycin $D$ and cycloheximide were added just before the cultures were exposed to $26^{\circ} \mathrm{C}$. While actinomycin D had no effect, cycloheximide inhibited both phenoloxidase $B$ and the increase in total proteolytic activity (Table I). Thus it is suggested 


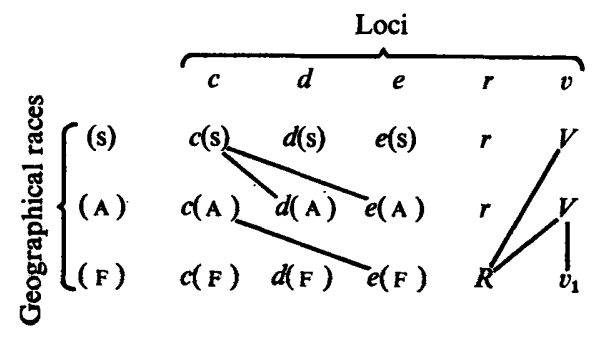

Fig. 2. Incompatibility relationships between the geographical races (A), (F) and (s) of Podospora anserina determined by alleles at the $c, d, e, r$ and $v$ incompatibility loci (from Bernet, 1967). Incompatible gene combinations are connected by a line: $R$ and $V$ for the $r$ and $v$ loci, for the $c, d$ and $e$ loci, $c(\mathrm{~s})$ and $d(\mathrm{~A})$ in the $C / D$ system, $c(\mathrm{~s})$ and $e(\mathrm{~A}), c(\mathrm{~A})$ and $e(\mathrm{~F})$ in the $C / E$ system, and $V$ and $v_{1}$ in the allelic $V / v_{1}$ system.

Table I. Effect of actinomycin $D$ and cycloheximide on phenoloxidase $B$ and on the level of proteolytic activity in $R V$ strains shifted from 32 to $26{ }^{\circ} \mathrm{C}$

Inhibitors were added 2 to $3 \mathrm{~h}$ before the temperature shift at final concentrations of $33 \mu \mathrm{g} / \mathrm{ml}$ for actinomycin $\mathrm{D}$ and $6 \mu \mathrm{g} / \mathrm{ml}$ for cycloheximide. In each experiment the first number corresponds to the measure at $32{ }^{\circ} \mathrm{C}$ and the second to that after $12 \mathrm{~h}$ incubation at $26^{\circ} \mathrm{C}$.

\begin{tabular}{llcc} 
& \multicolumn{3}{c}{ Inhibitor added } \\
\cline { 2 - 3 } & $\overbrace{\text { None }}$ & Actinomycin D Cycloheximide \\
Proteolytic activity & $0.5,2.9$ & $0.6,2.3$ & $0.7,0.8$ \\
Relative activity of phenoloxidase B & 0,100 & 0,100 & 0,10
\end{tabular}

that phenoloxidase B, like proteases III and IV, arises from preformed RNA messengers. To investigate whether the synthesis of phenoloxidase $B$ was induced simply as a consequence of the activity of proteases III and IV, i.e. by an increase in the lysing cells of the level of aromatic amino acids, the $R V$ strains were cultured at $32{ }^{\circ} \mathrm{C}$ on a medium containing high concentrations (100 mg/ml) of the three aromatic amino acids. In these conditions phenoloxidase B was always absent, suggesting that this enzyme arises, like proteases III and IV, as a consequence of the interaction between incompatible factors rather than being a secondary effect.

Phenoloxidases A and B were investigated in $R V$ strains that carry the $\bmod -I(I), \bmod -2(I)$ or $\bmod -\mathrm{I}(\mathrm{I})$ and $\bmod -2(I)$ mutations, at $32{ }^{\circ} \mathrm{C}$ and after $\mathrm{I} 2 \mathrm{~h}$ culture at $26^{\circ} \mathrm{C}$. Phenoloxidase $A$ was always present. Phenoloxidase $B$, whose synthesis is triggered off by the temperature shift, was affected only when the $R V$ strain carried both mod mutations, when the activity of this enzyme was reduced to less than $10 \%$ of that found in the three other genotypes. It may be concluded that the formation of phenoloxidase $B$ is under the same control as protease IV.

\section{Effect of incompatibility genes on the female fertility of the double mutant mod-I(I) mod-2(I) strains}

From the results reported above we saw that mod-I and mod-2 mutations affect three enzymes, proteases III and IV and phenoloxidase B, which appear during vegetative growth only as a consequence of the non-allelic gene interactions $C / D, C / E$ and $R / V$. Since mutations at mod-r and mod-2 genes also prevent the formation of female organs (Boucherie $\&$ Bernet, 1974), the incompatibility genes at the $c, d, e, r$ and $v$ loci, might also play a role in the formation of the protoperithecia. To test this hypothesis, several recombinant strains 


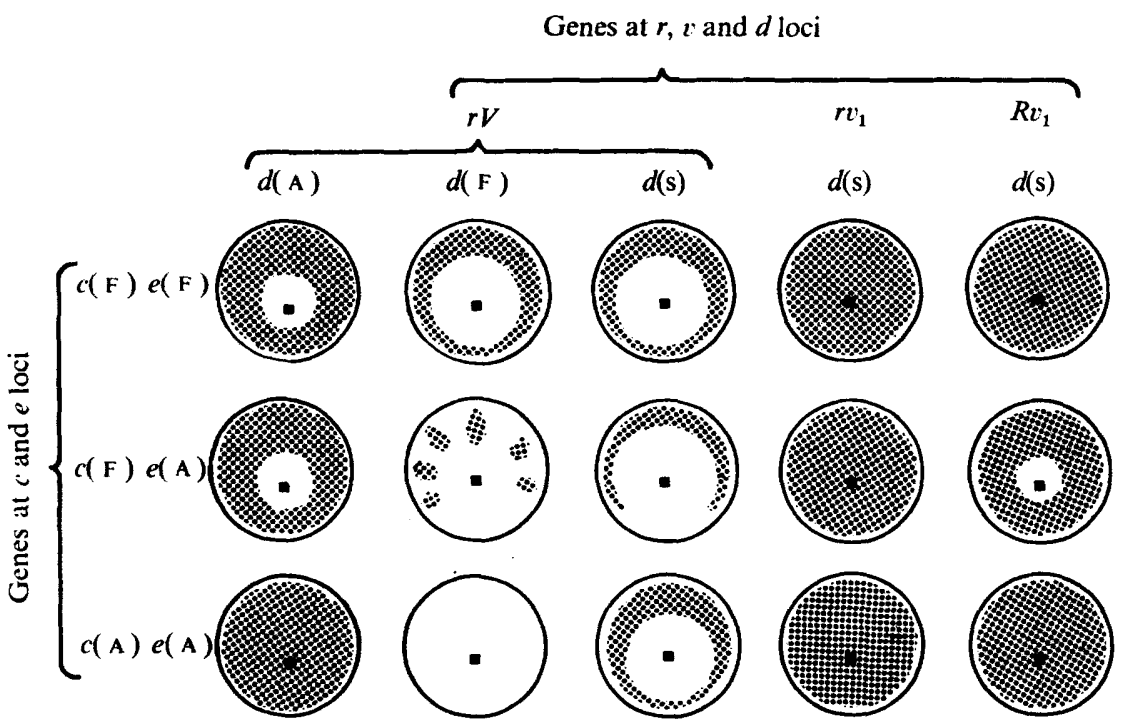

Fig. 3. Effect of alleles at the $c, d, e, r$ and $v$ loci on the distribution of protoperithecia in double

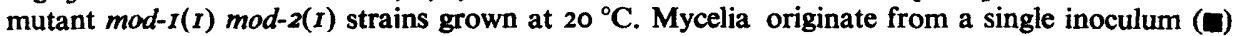
deposited off centre in order to observe the effect of the extent of radial growth.

were constructed by appropriate two-way and three-way crosses between the geographical races $(A),(F)$ and $(s)$ of the fungus. Incompatibility relationships between these races, involving loci $c, d, e, r$ and $v$, are shown in Fig. 2. In the progeny of the crosses, $C D$ [i.e. $c(\mathrm{~s}) d(\mathrm{~A})$ ], $C E$ [i.e. $c(\mathrm{~s}) e(\mathrm{~A})$ or $c(\mathrm{~A}) e(\mathrm{~F})]$ and $R V$ were lethal self-lysing genotypes in which growth stopped early in development and were discarded. Most of the viable genotypes were examined for female fertility. All the strains exhibited wild-type fertility. Protoperithecia started to form when the mycelium reached the edge of the Petri dish"and they eventually developed at a rather uniform density $\left(\mathrm{IO}^{3} / \mathrm{cm}^{2}\right)$ over the entire surface of the cultures.

Recombinant strains carrying the $\bmod -I(I)$ or the $\bmod -2(I)$ mutations showed normal female fertility. Strains carrying both $\bmod -I(I)$ and $\bmod -2(I)$ mutations were practically female sterile at $26{ }^{\circ} \mathrm{C}$, but showed a noticeable restoration of fertility at $20^{\circ} \mathrm{C}$. However, important differences in the distribution of protoperithecia over the surface of the mycelia were observed (Fig. 3). Investigations on eight strains of each genotype showed that the differences in female fertility depended solely on the $c d e r v$ genotype. None of the recombinant strains showed wild-type fertility because of the absence of protoperithecia in an outer area of the mycelium, 5 to $6 \mathrm{~mm}$ in width. In general, the most fertile strains were those carrying the $v_{1}$ gene from the (F) geographical race associated with $R$ from (F) or $r$ from (A). For the third viable combination at the $r$ and $v$ loci, i.e. the $r V$ genotype, derived from the (s) race, the female fertility depended on the nine $c d e$ combinations investigated. The three most sterile genotypes were formed with alleles of independent origin, i.e. $c(\mathrm{~F}) e(\mathrm{~A}) d(\mathrm{~F}), c(\mathrm{~F}) e(\mathrm{~A}) d(\mathrm{~S}), c(\mathrm{~A}) e(\mathrm{~A}) d(\mathrm{~F})$. Furthermore, for the strains that carried the $d(\mathrm{~A})$ or $d(\mathrm{~F})$ genes at the $d$ locus, the most fertile $c e$ combinations were $c(\mathrm{~A}) e(\mathrm{~A})$ for $d(\mathrm{~A})$ and $c(\mathrm{~F}) e(\mathrm{~F})$ for $d(\mathrm{~F})$.

From these results it can be concluded that the five incompatibility loci $c, d, e, r$ and $v$ are involved in protoperithecium formation, since at $20^{\circ} \mathrm{C}$ they suppress to various extents 
the inhibitory effect of the mod mutations. Moreover, it seems likely that the $c, d$ and $e$ incompatibility loci operate through the effect of specific combinations of these three genes, rather than through addition of their individual gene effects.

\section{DISCUSSION}

The effect of mutations at the mod-I and mod-2 genes on proteases A, B, C, III and IV and phenoloxidases A and B has been investigated. Only proteases III and IV and phenoloxidase $B$, whose messengers are normally latent during vegetative growth and which appear as novel proteins during the protoplasmic incompatibility reaction, depend on mod-I and $\bmod -2$ genes. The mod-I(I) mutation abolishes the activity of protease III. Although this mutation is recessive, mod-r is not the structural gene for protease III, because the product of mod-I, but not protease III, is sensitive to streptomycin and magnesium (Bernet, Bégueret \& Labarere, I973). From these latter properties it was postulated that mod-I determined a ribosomal factor which, from the present results, appears essential for the translation of the messenger of protease III. The mod-I factor also plays a role in the formation of protease IV and phenoloxidase B, since the mod-2(I) mutation suppresses these enzymes when it is in association with a mutation in mod-I. Because of this interaction with mod-I and the fact that mod-2(I) is dominant over its wild-type allele (Bernet et al. 1973), mod-2 is not thought to be the structural gene for protease IV but rather a regulator gene for protease IV and phenoloxidase B. Thus, the three non-allelic incompatibility interactions $C / D, C / E$ and $R / V$ have in common the induction from latent mRNA molecules of the synthesis of proteins that are also under the control of mod-I (protease III) or mod-I plus mod-2 (protease IV and phenoloxidase B).

The suppression of the formation of the female organs by the mod mutations also requires mutations in both mod genes (Boucherie \& Bernet, 1974). The restoration of female fertility to mod-r mod-2 strains by different allele combinations at the $c, d, e, r$ and $v$ incompatibility loci suggests that the latter also have a role in the formation of protoperithecia. Thus, protoplasmic incompatibility and protoperithecium formation are related phenomena, since we have shown that they are under the control of seven common loci: the $c, d, e, r$ and $v$ incompatibility loci and mod-I and mod-2. We consider that protoplasmic incompatibility arises from the deviant expression in vegetative cells of a physiological process normally involved in the formation of the female organs. On this hypothesis, protease IV and phenoloxidase B are essential for protoperithecial formation, and the function of the incompatibility genes is to induce the synthesis of these enzymes, following the cessation of vegetative growth.

This work was supported by the Centre National de la Recherche Scientifique: Equipe de Recherche Associée no. 485 et Action Thématique Programmée 'Différenciation cellulaire'.

\section{REFERENCES}

BÉgueret, J. (1972). Protoplasmic incompatibility: possible involvement of proteolytic enzymes. Nature New Biology 235, 56-58.

BÉguEReT, J. (1973). L'incompatibilité cellulaire chez le champignon Podospora anserina : étude physiologique de la réaction. Thèse Sciences Université de Bordeaux II.

Bégueret, J. \& Bernet, J. (1973a). Proteolytic enzymes and protoplasmic incompatibility in the fungus Podospora anserina. Nature New Biology 243, 94-96.

Bégueret, J. \& Bernet, J. (1973b). L'incompatibilité cellulaire chez le champignon Podospora anserina: déterminisme génétique et mécanisme physiologique de la réaction d'incompatibilité. In L'étude phylogénique et ontogénique de la réponse immunitaire et son apport à la théorie immunologique Ed, pp. I-15. Paris: Inserm. 
Bernet, J. (1967). Les systèmes d'incompatibilité chez le Podospora anserina. Comptes rendus hebdomadaire des séances de l'Académie des sciences $265,1330-1333$.

BERNET, J. (197I). Sur un cas de suppression de l'incompatibilité cellulaire chez le Podospora anserina. Comptes rendus hebdomadaire des séances de l'Académie des sciences 273, $1120-1122$.

Bernet, J., BÉgueret, J. \& LABARERE, J. (1973). Incompatibility in the fungus Podospora anserina: are the mutations abolishing the incompatibility reaction ribosomal mutations. Molecular and General Genetics 124, 35-50.

BlAICH, R. \& EsSER, K. (1971). The incompatibility relationships between geographical races of Podospora anserina. V. Biochemical characterization of heterogenic incompatibility on cellular level. Molecular and General Genetics III, 265-272.

BOUCHERIE, H. (1973). Etude des relations entre les phénomènes d'incompatibilité et de différenciation des organes reproducteurs femelles chez le champignon Podospora anserina. Thèse Doctorat de Spécialité Université Bordeaux II.

BOUCHERIE, H. \& BERNET, J. (1974). Protoplasmic incompatibility and female organ formation in Podospora anserina: properties of mutations abolishing both processes. Molecular and General Genetics 135 , 163-174.

CARLILE, M. J. \& DeE, J. (1967). Plasmodial fusion and lethal interaction between strains in a myxomycete. Nature, London 215, 832-834.

Coluns, O. R. \& Clark, J. (I968). Genetics of plasmodial incompatibility in a Honduran isolate of Didymium iridis. Mycologia 60, 90-103.

Esser, K. (1963). Die Phenoloxydasen des Ascomyceten Podospora anserina. Archiv für Mikrobiologie 46, 217-226.

EsSER, K. (1969). An introduction to Podospora anserina. Neurospora Newsletter 15, 27-3I.

GARNJOBST, L. \& WILSON, J. F. (1956). Heterokaryosis and protoplasmic incompatibility in Neurospora crassa. Proceedings of the National Academy of Sciences of the Uhited States of America 42, 613-618.

Rizet, G. \& Engelman, C. (1949). Contribution à l'étude d'un ascomycète tétrasporé: Podospora anserina. Revue de Cytologie et de Biologie végétales 2, 202-25I.

RIzET, G. \& Esser, K. (1952). Sur les phénomènes d'incompatibilité entre souches d'origines différentes chez le Podospora anserina. Comptes rendus hebdomadaire des séances de l'Académie des sciences 237, $760-763$. 